\title{
Transcriptional silencing of the Dickkopfs-3 (Dkk-3) gene by CpG hypermethylation in acute lymphoblastic leukaemia
}

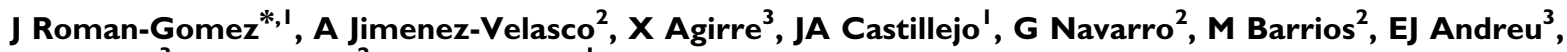 \\ F Prosper ${ }^{3}$, A Heiniger ${ }^{2}$ and A Torres
}

'Hematology Department, Molecular Biology Unit, Reina Sofia Hospital, 14004 Cordoba, Spain; ${ }^{2}$ Hematology Department, Molecular Biology Unit, Carlos Haya Hospital, Malaga, Spain; ${ }^{3}$ Hematology Department, Cellular Therapy Area, Clinica Universitaria/School of Medicine, Foundation for Applied Medical Research, University of Navarra, Pamplona, Spain

\begin{abstract}
Dkk-3 is a newly characterised mortalisation-related gene and an antagonist of the Wnt oncogenic signalling pathway whose expression is decreased in a variety of cancer cell lines, suggesting that the Dkk-3 gene, located at chromosome I I I I I. I, functions as a tumour suppressor gene. Although I I I 5 is a 'hot spot' for methylation in acute lymphoblastic leukaemia (ALL), the role of Dkk-3 abnormalities has never been evaluated in this disease. We analysed CpG island methylation of the Dkk-3 promoter in six ALL cell lines and $183 \mathrm{ALL}$ patients. We observed DKk-3 hypermethylation in all cell lines and in cells from 33\% (60/I83) of ALL patients. Moreover, Dkk-3 methylation was associated with decreased Dkk-3 mRNA expression and this expression was restored after exposure to the demethylating agent 5-AzaC. Clinical features did not differ between hypermethylated and unmethylated patients. Estimated disease-free survival (DFS) and overall survival at 10 and II years, respectively, were 49.8 and $45.6 \%$ for normal patients and 10.5 and $15.1 \%$ for hypermethylated patients $(P=0.001$ and 0.09$)$. Multivariate analysis demonstrated that $D k k-3$ methylation was an independent prognostic factor predicting DFS $(P=0.0009)$. Our data suggest that Dkk-3 methylation occurs at an early stage in $\mathrm{ALL}$ pathogenesis and probably influences the clinical behaviour of the disease.

British Journal of Cancer (2004) 91, 707-713. doi:10.1038/sj.bjc.6602008 www.bjcancer.com

Published online 29 June 2004

(c) 2004 Cancer Research UK
\end{abstract}

Keywords: acute lymphoblastic leukaemia; CpG island; methylation; Dkk-3

DNA methylation is an essential mechanism for the regulation of gene expression in mammalian cells (Bird, 2002). Methylation occurs at cytosine residues within $\mathrm{CpG}$ dinucleotides and many genes are enriched with these dinucleotides in their promoters. These regions are known as $\mathrm{CpG}$ islands and are generally nonmethylated, a condition that allows genes to be transcriptionally competent. Methylation of CpG islands within gene promoters leads to transcriptional silencing through recruitment of methylCpG binding protein and histone deacetylases (Jones and Baylin, 2002). Hence, identification of the methylation patterns of $\mathrm{CpG}$ islands in mammalian cells is important for understanding normal and pathological gene expression. Several reports have shown that abnormal hypermethylation of $\mathrm{CpG}$ islands may contribute significantly to the pathogenesis of human leukaemias. Hypermethylation of promoters associated with genes involved in the control of the principal late-G1 cell-cycle checkpoint, the apoptotic programme and the cell-cell adhesion is detected with increased frequency in acute lymphoblastic leukaemia (ALL) (Roman-Gomez et al, 2003). This mechanism provides an alternative route to gene mutation of cancer-related genes. Although genomewide methylation changes in CpG islands are early and frequent events in ALL,

*Correspondence: Dr J Roman-Gomez; E-mail: peperosa@teleline.es Received 23 February 2004; revised 28 April 2004; accepted 17 May 2004; published online 29 June 2004 it is also evident that some of these changes occur preferentially in specific chromosome regions. In this context, 11 p15 region seems to represent a 'hot spot' for methylation in ALL. In fact, epigenetic inactivation of Calcitonin (11p15.1-15.2), p57 (11p15.5) and Myf-3 (11p15.4) genes are frequently observed in both childhood and adult ALL (Roman-Gomez et al, 2001; Garcia-Manero et al, 2002; $\mathrm{Li}$ et al, 2002). Interestingly, Calcitonin gene is methylated in a large proportion of ALL patients with dismal prognosis. However, this gene is generally considered not to be causally related to the malignant process suggesting that its methylation is a surrogate for the methylation of another potential tumour suppressor gene located in its vicinity.

The human Dickkopfs-3 (Dkk-3) gene, located on chromosome $11 \mathrm{p} 15.1$ is a recently found mortalisation-related gene expression of which is largely attenuated in many immortalised and tumourderived cell lines (Tsuji et al, 2000). Furthermore, by transfection experiments, it has been determined that $D k k-3$ possesses an antiproliferative activity against tumour cells, suggesting that $D k k$ 3 may function as a tumour suppressor (Tsuji et al, 2001).

Recent studies have shown that some Dkks play a role in a wide range of normal and pathological developmental processes, including cancer, and that their effects seem to be mediated by their ability to antagonise Wnt signalling (Taipale and Beachy, 2001). Wnt signalling pathway has profound effects in normal haematopoiesis inducing bone marrow cells to develop into a variety of different lymphoid cell types and also augmenting 
repopulating capacity and primitive hematopoietic development of human blood stem cell in vivo (Brandon et al, 2000). In addition, expression of Wnt-16 following a chromosomal translocation has been reported in preB-cell ALL (McWhirter et al, 1999) and Wnt5a hemizygous mice develop myeloid leukaemias and B-cell lymphomas that are clonal in origin suggesting a role for Wnts in leukaemogenesis. However, little is known about the potential role of Wnt antagonists in lymphoid neoplasia.

In this paper, we demonstrate that the putative tumour suppressor $D k k-3$ gene is silenced by methylation in ALL and that this epigenetic event confers poor prognosis in this group of patients.

\section{MATERIALS AND METHODS}

\section{Cell lines and samples}

Four human precursor-B ALL (BV173, TOM-1, MY and NALM-20) and two T-cell leukaemia (MOLT-3 and MOLT-4) cell lines were obtained from the American Type Culture Collection (Manassas, VA, USA). The cells were cultured in the appropriate medium until harvested for extraction of DNA and RNA using standard procedures. Bone marrow samples obtained by aspiration were collected after an acquisition of informed consent from 183 consecutive patients (106 male; 77 female) who were diagnosed with de novo ALL between January 1989 and December 2002. Mononuclear cells were isolated from samples at diagnosis by a Ficoll-Paque gradient as per the manufacturer's instructions (Amersham Pharmacia Biotech AB, Uppsala, Sweden). In all the cases, the diagnostic bone marrow sample contained blast cells in the ratio of at least $70 \%$.

The median age at diagnosis in the study population as a whole was 14.5 years (range, 0.5-82 years). Of these patients, 92 were children (median age, 5 years; range, 0.5-14) and 91 presented adult ALL (median age, 35 years; range, 15-82). Diagnosis was established according to standard morphologic, cytochemical and cytogenetic criteria. Patients were studied at the time of initial diagnosis; were risk-stratified according to the therapeutic protocol used, which was always based on recognised prognostic features (including cytogenetics); and were entered in ALL protocols of the 'Programa para el estudio y tratamiento de las hemopatias malignas' (PETHEMA) Spanish study group. For statistical analyses, children were also grouped according to the National Cancer Institute (NCI) risk-classification criteria (Smith et al, 1996). The specific PETHEMA ALL treatment protocols in which these patients entered included ALL-89 (between 1989 and 1994; $n=53$ ) and ALL-93 (between 1994 and 2002; $n=130$ ). The design and results of these studies have been previously reported (Ortega, 1998; Ribera et al, 1998; Ortega et al, 2001; Ribera et al, 2002). In all, 64 patients relapsed. Overall, 29 patients received stem cell transplantation (10 autologous, 19 allogeneic) in the first $(n=12)$ or second complete remission (CR) $(n=17)$. There are 91 patients currently alive. Clinical characteristics of the patients are listed in Table 1 . Some of these patients $(n=105)$ were typed previously for methylation of the Calcitonin gene (Roman-Gomez et al, 2001).

\section{Quantitative real-time PCR (qrt-PCR) for D $k$ k-3 expression}

Total RNA was extracted from mononuclear marrow cells with Ultraspec (Biotecx, Houston, TX, USA) following the manufacturer's instructions. Reverse transcription was performed on $1 \mu \mathrm{g}$ total RNA, after heating at $70^{\circ} \mathrm{C}$ for $5 \mathrm{~min}$, with random hexamers as reaction primer. The reaction was carried out at $42^{\circ} \mathrm{C}$ for $45 \mathrm{~min}$ in the presence of $12 \mathrm{U}$ Avian Myeloblastosis virus reverse transcriptase (Boehringer-Mannhein, Germany). qrt-PCR was performed in a rapid fluorescent thermal cycler with three-colour fluorescence monitoring capability (LightCycler, Roche), using $1 \mu \mathrm{l}$ of cDNA in $20 \mu \mathrm{l}$ reaction volume with $0.4 \mu \mathrm{moll}^{-1}$ each primer, and $2 \mu \mathrm{l}$ of $10 \times$ LightCycler FastStar DNA Master SYBR Green I (Roche Molecular Biochemicals). The final $\mathrm{Mg}^{2+}$ concentration in the reaction mixture was adjusted to $3.5 \mathrm{mmoll}^{-1}$. Primer set was specific for the $D k k-3$ gene ( Homo sapiens Dkk-3 mRNA, GeneBank: AB033421; sense, 5'-CTGTGTGTCTGGGGTCACTG-3'; antisense, $5^{\prime}$-GCTCTAGCTCCCAGGTGATG- $3^{\prime}$ ). The following programme conditions were applied for qrt-PCR running: denaturation programme, consisting of one cycle at $95^{\circ} \mathrm{C}$ for $8 \mathrm{~min}$; amplification programme, consisting of 45 cycles at $95^{\circ} \mathrm{C}$ for $5 \mathrm{~s}, 60^{\circ} \mathrm{C}$ for $10 \mathrm{~s}$ and $72^{\circ} \mathrm{C}$ for $15 \mathrm{~s}$; melting programme, one cycle at $95^{\circ} \mathrm{C}$ for $0 \mathrm{~s}, 40^{\circ} \mathrm{C}$ for $60 \mathrm{~s}$ and $90^{\circ} \mathrm{C}$ for $0 \mathrm{~s}$; and cooling programme, one cycle at $40^{\circ} \mathrm{C}$ for $60 \mathrm{~s}$. The temperature transition rate was $20^{\circ} \mathrm{C} \mathrm{s}^{-1}$, except in the melting programme, which was $0.4^{\circ} \mathrm{C} \mathrm{s}^{-1}$ between 40 and $90^{\circ} \mathrm{C}$.

Amplification of Glyceraldehyde-3-phosphate dehydrogenase $(G A P D H)$ gene transcript was performed to assess RNA integrity and as reference gene (forward, 5'-TGAAGGTCGGAGTCAACGGATTTGGT-3'; reverse, 5'-CATGTGGGCCATGAGGTCCACCAC$\left.3^{\prime}\right)$. It was amplified in the same run and following the same procedure described above for $D k k-3$. In order to reduce the variation between different assays and samples, a procedure based on the relative quantification of target genes $v s$ their controls in relation to the reference gene was used. Calculations were automatically performed by LightCycler software (RealQuant, version 1.0, Roche). The normalised ratio was obtained from the next equation and expressed as percentage of the control:

$$
\begin{aligned}
& \text { Normalised ratio }\left(N_{\mathrm{DDK}-3}\right)= \\
& \quad\left(E_{\text {target }}\right)^{\Delta \text { Cptarget }(\text { control-sample })} \div\left(E_{\text {ref }}\right)^{\Delta \text { Cp ref(control-sample })}
\end{aligned}
$$

Efficiencies $(E)$ of each gene were calculated from the slopes of crossover points ( $\mathrm{Cp}$ ) vs cDNA concentration plot, according to the formula $E=10^{(-1 / \text { slope })} . \Delta \mathrm{Cp}$ corresponded to the difference between control $\mathrm{Cp}$ and sample $\mathrm{Cp}$, either for the target or for the reference genes. The selected control was the bone marrow specimen from a healthy donor. It was considered as $100 \%$ expression. Occasionally, equal amounts of PCR products were separated on a $2 \%$ agarose gel, stained with ethidium bromide, and visualised under UV light.

\section{Methylation-specific PCR (MSP) of $D k k$-3 promoter}

Analysis of the Dkk-3 gene (GeneBank: AB045205, Homo sapiens $D k k-3$ gene) has revealed that $D k k-3$ promoter was CpG-rich, showing $>60 \% \mathrm{C}+\mathrm{G}$ content and an observed-overexpected $\mathrm{CpG}$ frequency of $>0.6$, satisfying the criteria for a $\mathrm{CpG}$ island. Aberrant promoter methylation of $D k k-3$ gene was determined by method of MSP as previously reported (Herman et al, 1996). MSP distinguishes unmethylated alleles of a given gene based on DNA sequence alterations after bisulphite treatment of DNA, which converts unmethylated but not methylated cytosines to uracils. Subsequent PCR using primers specific to sequences corresponding to either methylated or unmethylated DNA sequences was then performed. Primer sequences of $D k k-3$ for the unmethylated reaction were forward ( $5^{\prime}$-TTTTGGTTTTTTTTTGTTTTTGGG-3') and reverse $\left(5^{\prime}\right.$-CCAAACCACTACATCTCCACT- $\left.3^{\prime}\right)$, which amplify a 179-bp product. Primer sequences for the methylated reaction were forward $\left(5^{\prime}\right.$-CGGTTTTTTTTCGTTTTCGGG-3 $\left.{ }^{\prime}\right)$ and reverse (5'-CAAACCGCTACATCTCCGCT-3'), which amplify a 175-bp product. Briefly, $1 \mu \mathrm{g}$ of genomic DNA were denatured by treatment with $\mathrm{NaOH}$ and modified by sodium bisulphite. DNA samples were purified using Wizard DNA purification resin (Promega Corp., Madison, WI, USA), treated with $\mathrm{NaOH}$, precipitated with ethanol, and resuspended in $20 \mu \mathrm{l}$ of water. A volume of $2 \mu \mathrm{l}$ of modified DNAs were PCR amplified in a 
total volume of $50 \mu \mathrm{l}$. 'Hot start' PCR was performed for 35 cycles consisting of denaturation at $95^{\circ} \mathrm{C}$ for $1 \mathrm{~min}$, annealing at $60^{\circ} \mathrm{C}$ for $1 \mathrm{~min}$, and extension at $72^{\circ} \mathrm{C}$ for $1 \mathrm{~min}$, followed by a final 7-min extension for all primer sets. DNA from mononuclear marrow cells $(n=20)$ from healthy donors were used as negative controls for methylation-specific assays. Human male genomic DNA universally methylated for all genes (Intergen Company, Purchase, NY, USA) was used as a positive control for methylated alleles. Water blanks were included with each assay. PCR products were visualised on $2 \%$ agarose gels stained with ethidium bromide. Results were confirmed by repeating bisulphite treatment and MSP assays for all samples. The sensitivity of this MSP was established by using totally methylated, positive control DNA serially diluted by normal lymphocyte DNA. MSPs with 1:10, 1:100, and $1: 1000$ diluted positive control DNA produced detectable methylated bands (data not shown).

\section{Western blot analysis of Dkk-3 protein expression}

For immunoblotting, proteins were extracted from B-lineage ALLderived MY cell line and MY cell line treated with 1,2, 4 or $6 \mu \mathrm{M}$ of 5-Aza-2'-deoxycytidine during 4 days. Cells from MY and treated MY cell lines were washed in PBS and lysed in Triton lysis buffer (1\% Triton X-100, $50 \mathrm{~mm}$ Tris- $\mathrm{HCl} \mathrm{pH} 8,150 \mathrm{~mm} \mathrm{NaCl}, 1 \mathrm{~mm}$ PMSF and $1 \%$ aprotinin). The supernatant was collected by centrifugation at $15000 \mathrm{~g}, 20 \mathrm{~min}, 4^{\circ} \mathrm{C}$, and the protein concentration was determined using BCA protein assay kit (Pierce, Rockford, IL, USA). Cell lysates (containing $50 \mu \mathrm{g}$ of proteins) were sizefractionated by $10 \%$ SDS-PAGE and electrotransferred to nitrocellulose membranes. The membranes were blocked with IBlock $^{\mathrm{TM}}$ (Tropix, Bedford, MA, USA) and incubated for $2 \mathrm{~h}$ with goat polyclonal antibody against Dkk-3 (Santacruz Biotechnology, Santa Cruz, CA, USA) diluted $1: 750$ and then with donkey antigoat antibody conjugated to alkaline phosphatase (Promega, Madison, WI, USA) diluted 1:15000 for $45 \mathrm{~min}$. As loading control, the membranes were incubated for $1 \mathrm{~h}$ with mouse monoclonal antibody against $\beta$-tubulin diluted $1: 1000$ and then with goat anti-mouse antibody conjugated to alkaline phosphatase (Sigma, Steinheim, Germany) diluted 1:10000 for 45 min. Finally, bound antibodies were detected by a chemiluminescence system (Tropix, Bedford, MA, USA). For detection of secreted proteins, $20 \mu \mathrm{l}$ of filtered, dialysed, conditioned media, collected after $48 \mathrm{~h}$ of incubation with MY and treated MY cell lines, was analysed by Western blotting.

\section{Statistical analysis}

$P$-values for comparisons of continuous variables between groups of patients were two-tailed and based on the Wilcoxon rank-sum test. $P$-values for dichotomous variables were based on the Fisher exact test. The remaining $P$-values were based on the Pearson $\chi^{2}$ test. Overall survival (OS) was measured from the day of diagnosis until death from any cause and was only censored for patients known to be alive at last contact. Disease-free survival (DFS) was measured from the day that complete response (CR) was established until either relapse or death without relapse, and it was only censored for patients who were alive without evidence of relapse at the last follow-up. Distributions of OS and DFS curves were estimated by the method of Kaplan and Meier with $95 \%$ confidence intervals calculated using Greenwood's formula. Comparisons of OS or DFS between groups were based on the log-rank test. Comparisons adjusted for significant prognostic factors were based on Cox regression models and hazard regression models. All relapse and survival data were updated on 31 December 2003 and all follow-up data were censored at this point.

\section{RESULTS}

\section{$D k k$-3 expression is downregulated in ALL samples and T/B-precursor ALL cell lines}

To determine the cutoff point for altered $D k k-3$ expression in ALL samples, the $N_{\text {DDK-3 }}$ value for $D k k-3$ was determined in 20 bone marrow samples from healthy donors. $N_{\text {DDK-3 }}$ values fell between 107 and $86 \%$ (mean: $96.5 \pm 5.6 \%$ ). A $N_{\text {DDK-3 }}$ value below $68.5 \%$ (determined as the mean \pm 5 s.d.) was chosen to define underexpression of $D k k-3$ in ALL RNA samples. No $D k k-3$ expression was observed in T- or B-precursor ALL cell lines (Figure 1B). In addition, we found a strong reduction of $D k k-3$ mRNA in $41 \%$ of diagnostic ALL samples ( $N_{\text {DDK-3: }}$ mean, $23 \%$; range, $\left.47-0 \%\right)$. No overexpression of $D k k-3\left(N_{\mathrm{DDK}-3}\right.$ above $\left.107 \%\right)$ was observed in ALL primary tumours.

\section{Methylation of $D k k-3$ promoter is associated with reduced mRNA expression}

To investigate a mechanism for the reduced expression of the $D k k$ 3 gene, we analysed $D k k-3$ promoter, which is known to be methylated in cancer cell lines lacking $D k k-3$ expression (Kobayashi et al, 2002). Promoter of the Dkk-3 gene has a typical CpG island showing $>60 \% \mathrm{C}+\mathrm{G}$ content and an observed-overexpected CpG frequency of $>0.6$. By MSP, CpG island of the $D k k-3$ promoter was revealed to be highly methylated in all ALL cell lines (Figure 1A) and in 60 of 183 (33\%) samples from patients with ALL (Figure 1C), which was clearly in contrast to no Dkk-3 methylation in normal cells.

All 60 methylated ALLs (100\%) showed decreased Dkk-3 expression; in contrast, decreased $D k k-3$ expression was detected in only 10 of 123 ALLs with unmethylated pattern (8\%). This result indicated that CpG methylation within $D k k-3$ promoter strongly correlated with decreased constitutive expression of $D k k-3$ in ALL cells $(P<0.0001)$.

Exposure to different concentration of the demethylating agent 5-Aza-2'-deoxycytidine restored, in both cell lysate and culture supernatant, the expression of Dkk-3 protein in the MY ALL cell line indicating that hypermethylation is a major mechanism by which Dkk-3 expression is silenced in ALL cells (Figure 1D).

Dkk-3 methylation, clinical presentation and outcome: Dkk-3 methylation was detected at diagnosis in 33\% (60 out of 183) of patients with adult or childhood ALL of all the FAB subtypes. As shown in Table 1, aberrant Dkk-3 methylation was similarly observed in adults (30 out of 91, 33\%) and children (30 out of 92, $32 \%)$. Clinical and laboratory features did not differ significantly between methylated and normal patients. Poor-risk cytogenetics or molecular events, risk groups according to both NCI or PETHEMA classifications, good risk features (hyperdiploidy and TEL-AML1 fusion), type of PETHEMA protocol administered and number of patients who received stem cell transplantation were similarly distributed between the two groups defined by Dkk-3 methylation. Separate analysis of adult and childhood ALL patients gave the same results as the global series. The presence of methylation in the Calcitonin gene was determined previously for 105 of these cases (Roman-Gomez et al, 2001). There was a significant concordance between Dkk-3 methylation and the presence of Calcitonin methylation; methylation was present in 30 out of 42 (71.4\%) Calcitonin-methylated tumours vs 13 out of $63(20.6 \%)$ Calcitonin nonmethylated tumours $(P=0.0001)$.

Table 1 details the relapse history, $C R$ rates and mortality for patients who exhibited Dkk-3 methylation and the equivalent data for patients with normal $D k k-3$ gene. CR rates of patients with normal and methylated $D k k-3$ gene were 90 and $92 \%$, respectively, accounting for $91 \%$ of the overall CR rate. This suggests that methylation of the $D k k-3$ gene did not correlate with response to remission induction therapy. However, methylated patients had a 


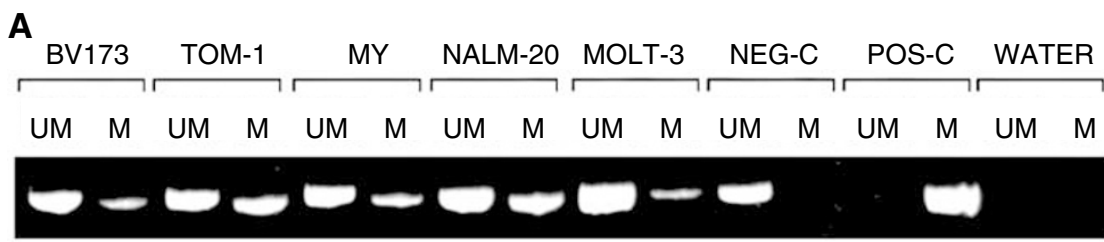

B

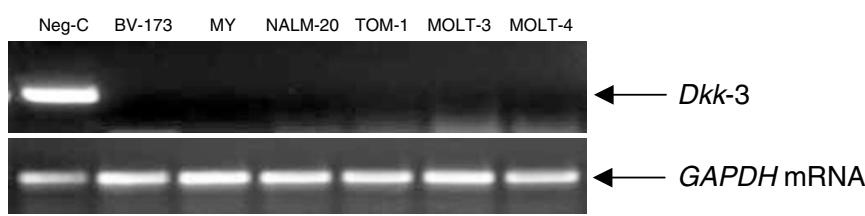

C

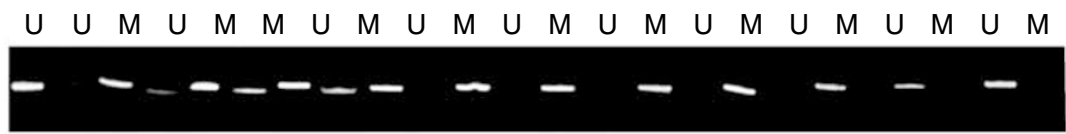

D

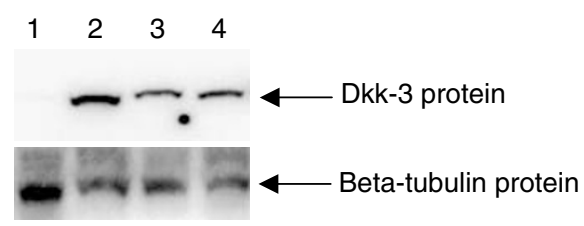

Figure I Methylation status and expression levels of Dkk-3 in ALL cell lines and patients. (A) MSP analysis of CpG island within Dkk-3 promoter in five ALL cell lines. Pos- $\mathrm{C}$ indicates methylated control; Neg-C indicates unmethylated control (marrow mononuclear cells from a healthy donor); UM = unmethylated alleles; $M=$ methylated alleles. Promoter hypermethylation is observed in all cell lines. (B) RT-PCR analysis with the Dkk-3 and GAPDH (as control for mRNA integrity) primers. Neg-C indicates unmethylated control. Lack of Dkk-3 expression in observed in all cell lines. (C) MSP analysis of CpG island within Dkk-3 promoter in 12 ALL patients. (D) Analysis of Dkk-3 protein expression by Western blot. The levels of beta-tubulin were also analysed as loading control. I: ALL-derived MY cell line; 2-4: MY cell line treated with 2, 4 or $6 \mathrm{mM}$ of 5-Aza-2'-deoxycytidine. The demethylating agent restores Dkk-3 expression.

higher relapse rate $(57.7$ ss $34.7 \%, P=0.009)$ than nonmethylated patients. Similar results were obtained in the separate analyses of children (relapse rate: 46 vs 25\%, $P=0.04$ ) and adults (relapse rate: 71 vs $45 \%, P=0.03)$.

We analysed the DFS among patients who achieved CR according to Dkk-3 methylation. Estimated DFS rates at 10 years were 49.8 and $10.5 \%$ for normal and methylated patients, respectively $(P=0.001)$ (Figure $2 \mathrm{~A})$. Among unmethylated children, the 10 years DFS was $60.6 \%$ contrasting with $17.6 \%$ for hypermethylated children $(P=0.03$, Figure $2 \mathrm{~B})$. Among adult ALL patients, the 9-years DFS was $6.8 \%$ for methylated cases and $37.7 \%$ for normal cases $(P=0.01$, Figure $2 \mathrm{C})$. The actuarial OS calculated for all leukaemic patients was 45.6 and $15.1 \%$ at 11 years for cases with normal and hypermethylated $D k k-3$ gene, respectively $(P=0.09)$.

A multivariate analysis of potential prognostic factors (including the type of PETHEMA protocol applied) demonstrated that methylation of the $D k k-3$ gene was an independent prognostic factor in predicting DFS in the global series and also in both, childhood and adult ALL (Table 2).

\section{DISCUSSION}

Mammalian cells have a finite replicative potential in vitro and in vivo referred to as the Hayflick limit (Hayflick, 1997). Upon reaching this limit, cells cease to divide and undergo genetic, biochemical and morphological changes indicative of ageing, a state referred to as cellular senescence. As these cells do not proliferate, it has been suggested that cellular senescence is a major barrier against cancerous transformation. The ability to overcome senescence and obtain a limitless replicative potential (termed immortalisation), is one of the prerequisites for tumour transformation (Hanahan and Weinberg, 2000). If downregulation of a gene can lead to the immortalisation of cells, the gene may be a candidate of tumour suppressor gene. Recently, a mortalisationrelated gene was isolated by the representational difference analysis system with an immortalised cell line and the normal counterpart (Tsuji et al, 2000). A search of this gene revealed that it was identical with the human $D k k-3$ gene, an antagonist of the Wnt oncogenic pathway. More recently, it has been reported that $D k k-3$ expression was reduced by methylation in several cancer cell lines and primary lung cancers (Kobayashi et al, 2002).

$D k k-3$ gene could be a good candidate for epigenetic inactivation in ALL. It is located near the Calcitonin gene, a gene known to be methylated in ALL patients with unfavourable prognosis (RomanGomez et al, 2001). However, this gene is generally considered not to be causally related to the malignant process, suggesting that methylation status of the Calcitonin gene region in ALL lymphoblasts may well correspond to that of its neighbouring $D k k-3$ gene. In this study, we have identified the $D k k-3$ gene as a target gene for methylation and silencing in ALL. Dkk-3 locus methylation was detected in six ALL-derived cell lines and in 33\% of tumours at diagnosis, indicating that inactivation of the $D k k-3$ gene is a frequent and early event in the process of tumorigenesis in this disease. Methylation of the $D k k-3$ promoter region was associated with loss of $D k k-3$ gene expression in neoplastic cells and this expression was restored after exposure to the 
Table I Clinical characteristics and outcome of I83 ALL patients according to $D k k-3$ gene methylation status

\begin{tabular}{|c|c|c|c|}
\hline Feature & $\begin{array}{l}\text { Nonmethylated } \\
(n=123), \%\end{array}$ & $\begin{array}{c}\text { Methylated } \\
(n=60), \%\end{array}$ & $P$ \\
\hline \multicolumn{3}{|l|}{ Age } & \multirow[t]{4}{*}{ NS } \\
\hline Younger than 15 years & 48 & 52 & \\
\hline \multirow{2}{*}{\multicolumn{3}{|c|}{$\begin{array}{l}\text { Older than } 15 \text { years } \\
\text { Sex }\end{array}$}} & \\
\hline & & & \\
\hline WBC & & & \multirow{3}{*}{ NS } \\
\hline Below $50 \times 10^{9} 1^{-1}$ & 78 & 70 & \\
\hline Above $50 \times 10^{9} 1^{-1}$ & 22 & 30 & \\
\hline \multicolumn{3}{|l|}{ FAB classification } & \multirow[t]{4}{*}{ NS } \\
\hline LI & 38 & 25 & \\
\hline L2 & 50 & 64 & \\
\hline L3 & 12 & 11 & \\
\hline \multicolumn{3}{|l|}{ Blast lineage } & \multirow[t]{3}{*}{ NS } \\
\hline B & 88 & 64 & \\
\hline T & 12 & 36 & \\
\hline \multicolumn{3}{|l|}{$\mathrm{NCl}$ risk groups } & \multirow[t]{3}{*}{ NS } \\
\hline Standard & 80 & 65 & \\
\hline Poor & 20 & 35 & \\
\hline \multicolumn{3}{|l|}{ Pethema risk groups } & \multirow[t]{3}{*}{ NS } \\
\hline Standard & 40 & 34 & \\
\hline Poor & 60 & 66 & \\
\hline \multicolumn{3}{|l|}{ Treatment } & \multirow[t]{3}{*}{ NS } \\
\hline Pethema 89 & 25 & 27 & \\
\hline Pethema 93 & 75 & 73 & \\
\hline BMT & 19 & 10 & NS \\
\hline \multicolumn{3}{|l|}{ Best response } & \multirow[t]{2}{*}{ NS } \\
\hline CR & 90 & 92 & \\
\hline \multicolumn{4}{|l|}{ Cytogenetic/molecular } \\
\hline Abnormalities & & & NS \\
\hline BCR-ABL & 17 & 14 & \\
\hline$t(1 ; 19)$ & 4 & 2 & \\
\hline 11 q23 & 3 & 3 & \\
\hline c-Myc & 6 & 8 & \\
\hline $7 q 35-14 q 11$ & 6 & 8 & \\
\hline Hyperdiploidy & 9 & 5 & \\
\hline TEL-AML I & 5 & 3 & \\
\hline Normal & 46 & 52 & \\
\hline Others & 3 & 3 & \\
\hline NT & 1 & 2 & \\
\hline Relapse & 34 & 57 & 0.009 \\
\hline Death & 41 & 48 & NS \\
\hline
\end{tabular}

Data are expressed as percentages; $\mathrm{WBC}=$ white bood count; $F A B=$ FrenchAmerican-British; $\mathrm{NCl}=$ National Cancer Institute; PETHEMA = Programa para el estudio y tratamiento de las hemopatias malignas; $\mathrm{BMT}=$ bone marrow transplantation; $C R=$ complete remission.

demethylating agent 5-AzaC, indicating that hypermethylation is a major mechanism by which $D k k-3$ expression is silenced in ALL cells. Moreover, a significant concordance between Dkk-3 methylation and Calcitonin methylation was observed, suggesting that Calcitonin methylation is a surrogate for the methylation of the Dkk-3 gene.

What is the functional significance underlying the methylationmediated transcriptional loss of $D k k-3$ in ALL? During replicative senescence altered expression of genes that are involved in cell cycle control and oncogenesis is well documented. A senescencelike arrest can be induced by ectopic expression of $p 15^{I N K 4 b}$,
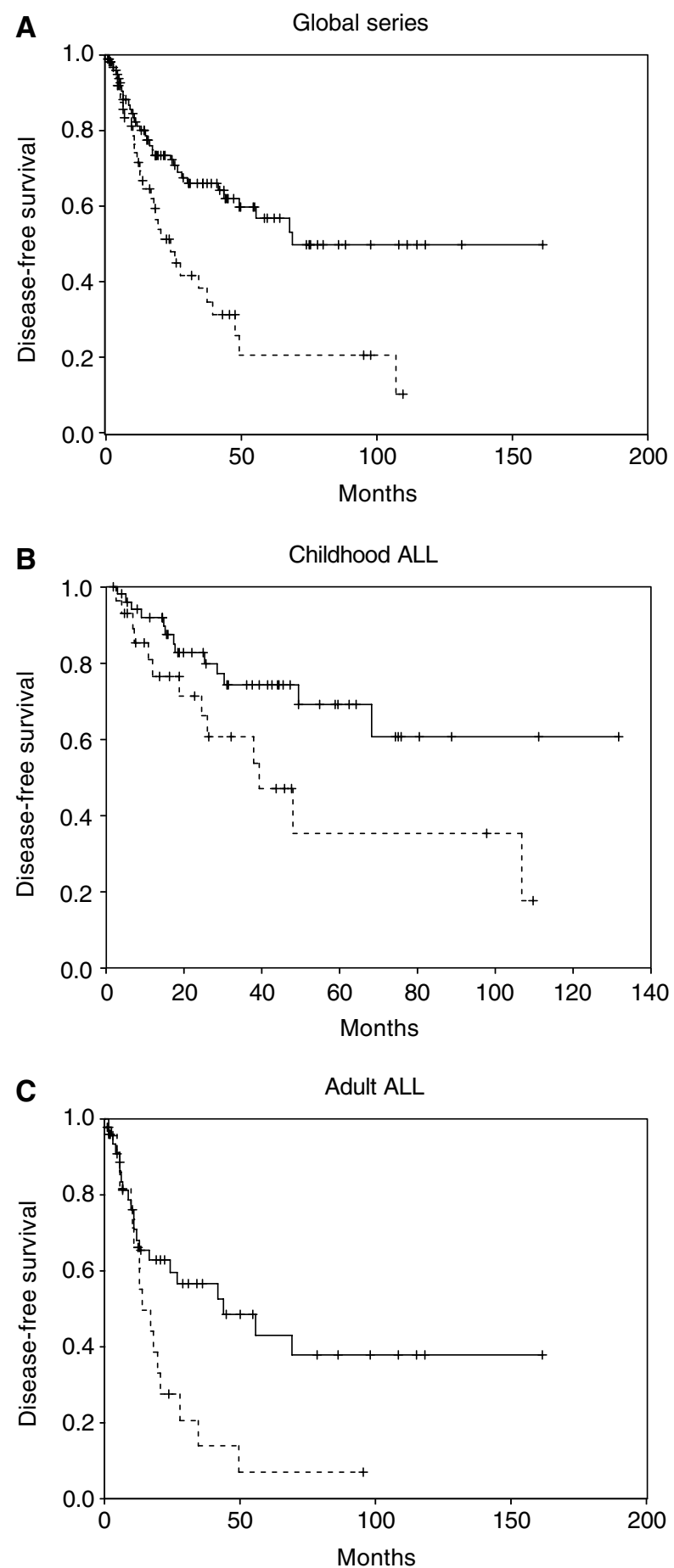

Figure 2 Kaplan-Meier survivor function for ALL patients. DFS curves for ALL patients enrolled in this study according to methylation status of the Dkk-3 gene. Solid lines, unmethylated patients; dashed lines, methylated patients.

$p 16^{I N K 4 a}, p 21^{C I P}$ or by DNA-damaging agents that activate $p 53$ (Serrano et al, 1997; Stein et al, 1999). These findings are consistent with a model in which the concurrent induction of a mitogenic stimulus with a forced $G_{1}$ arrest may be sufficient to induce a senescent phenotype. Senescence, much like apoptosis, represents a major barrier to tumorigenesis and it can be achieved by shortened telomeres or conflicting growth signals that forces 
Table 2 Multivariate Cox model for disease-free survival

\begin{tabular}{|c|c|c|}
\hline Feature & $\begin{array}{c}\text { Univariate analysis } \\
P \text {-value }\end{array}$ & $\begin{array}{c}\text { Multivariate analysis } \\
\qquad \text {-value }\end{array}$ \\
\hline \multicolumn{3}{|l|}{ Global series } \\
\hline Dkk-3 hypermethylation & 0.0004 & 0.0009 \\
\hline$W B C>50000 \mathrm{~mm}^{3}$ & $<0.0001$ & 0.01 \\
\hline BCR-ABL positivity & 0.02 & 0.01 \\
\hline T phenotype & 0.007 & 0.05 \\
\hline Age $>15$ years & 0.05 & - \\
\hline Pethema poor risk & 0.05 & - \\
\hline \multicolumn{3}{|l|}{ Childhood ALL } \\
\hline Dkk-3 hypermethylation & 0.003 & 0.003 \\
\hline T phenotype & 0.05 & 0.04 \\
\hline WBC $>50000 \mathrm{~mm}^{3}$ & 0.02 & - \\
\hline \multicolumn{3}{|l|}{ Adult ALL } \\
\hline WBC $>50000 \mathrm{~mm}^{3}$ & 0.0001 & 0.0006 \\
\hline Dkk-3 hypermethylation & 0.05 & 0.05 \\
\hline BCR-ABL positivity & 0.009 & - \\
\hline
\end{tabular}

aberrant cells into a $\mathrm{G}_{0}$-like state (Hanahan and Weinberg, 2000). The genetic changes associated with immortalisation, namely loss of $p 16, p 15, p 21$ and $p 53$, are among the most common known cancer-related changes, and these genes are frequently downregulated by methylation in ALL (Garcia-Manero et al, 2002 Roman-Gomez et al, 2002; Agirre et al, 2003). Dkk-3 could function in a similar way, confirming that epigenetic inactivation of genes involved in senescence regulation plays a major role in the pathogenesis of leukaemia. In addition, $D k k-3$ could contribute to

\section{REFERENCES}

leukaemogenesis by means of its ability to antagonise Wnt proteins. Wnt pathway plays a crucial role in haematopoietic differentiation (Brandon et al, 2000); and activation of a 'canonical' Wnt pathway is associated with several types of human cancers, including B-cell malignancies (Qiang et al, 2003). The 'transforming activity' of Wnt is ascribed to the beta-catenin/ signalling pathway, which appears to be specifically activated by Wnt7A protein (Sheldahl et al, 1999). Interestingly, Dkk-3 negatively modulates Wnt7A signalling (Caricasole et al, 2003). Therefore, it can be speculated that lack of $D k k-3$ expression favours the activation of the most powerful Wnt protein related to the development of cancer.

These findings, together with the prognostic impact of $D k k-3$ inactivation in ALL, the general expression of $D k k-3$ in normal blood cells, the emerging role of the $D k k-3$ gene in human cancer and the observation that transfection of human osteosarcoma Saos-2 cells with $D k k-3$ entails a decrease in the proliferative activity are supportive of $D k k-3$ inactivation contributing directly to the clinical behaviour of ALL, at least in a subgroup of patients.

In conclusion, our results strongly indicate that the silencing of $D k k-3$ expression by aberrant promoter methylation occurs at an early stage of ALL pathogenesis and plays a role in the outcome of the disease.

\section{ACKNOWLEDGEMENTS}

Supported by grants from Fondo de Investigaciones Sanitarias (FIS, Spain) PI030141, 01/0013-01, 01/F018, 02/1299; Navarra Goverment (31/2002); RETIC C03/10, Junta de Andalucia 03/143; 03/144 and funds from Cajamar-Fundacion Hospital Carlos Haya (Malaga, Spain).
Agirre X, Vizmanos JL, Calasanz MJ, Garcia-Delgado M, Larrayoz MJ, Novo FJ (2003) Methylation of CpG dinucleotides and/or CCWGG motifs at the promoter of TP53 correlates with decreased gene expression in a subset of acute lymphoblastic leukemia patients. Oncogene 22: $1070-1072$

Bird A (2002) DNA methylation patterns and epigenetic memory. Genes Dev 16: 6-21

Brandon C, Eisemberg LM, Eisemberg CA (2000) WNT signaling modulates the diversification of hematopoietic cells. Blood 96: $4132-4141$

Caricasole A, Ferraro T, Iacovelli L, Barletta E, Caruso A, Melchiorri D, Terstappen GC, Nicoletti (2003) Functional characterization of Wnt7a signalling in PC12 cells: interaction with a FZD5/LRP6 receptor complex and modulation by DKK proteins. J Biol Chem 278: 37024-37031

Garcia-Manero G, Daniel J, Smith TL, Kornblau SM, Lee MS, Kantarjian HM, Issa JP (2002) DNA methylation of multiple promoter-associated CpG islands in adult acute lymphoblastic leukemia. Clin Cancer Res 8: $2217-2224$

Hanahan D, Weinberg RA (2000) The hallmarks of cancer. Cell 100: 57 - 70

Hayflick L (1997) Mortality and immortality at the cellular level: a review. Biochemistry 62: $1180-1190$

Herman JG, Graff JR, Myohanen S, Nelkin BD, Baylin SB (1996) Methylation-specific PCR: a novel PCR assay for methylation status of CpG islands. Proc Natl Acad Sci USA 93: $9821-9826$

Jones PA, Baylin SB (2002) The fundamental role of epigenetic events in cancer. Nat Rev 3: $415-428$

Kobayashi K, Ouchida M, Tsuji T, Hanafusa H, Miyazaki M, Namba M, Shimizu N, Shimizu K (2002) Reduced expression of the REIC/Dkk-3 gene by promoter-hypermethylation in human tumor cells. Gene 282: $151-158$

Li Y, Nagai H, Ohno T, Yuge M, Hatano S, Ito E, Mori N, Saito H, Kinoshita $\mathrm{T}$ (2002) Aberrant DNA methylation of p57kip2 gene in the promoter region in lymphoid malignancies of B-cell phenotype. Blood 100: $2572-2577$
McWhirter JR, Neuteboom ST, Wancewicz EV, Monia BP, Downing JR, Murre C (1999) Proc Natl Acad Sci USA 96: 11464-11469

Ortega JJ (1998) Spanish acute lymphoblastic leukemia trials. Int J Pediat Hemat Oncol 5: 163-176

Ortega JJ, Ribera JM, Oriol A, Bastida P, Gonzalez ME, Calvo C, Egurbide I, Hernandez Rivas JM, Rivas C, Alcala A, Besalduch J, Macia J, Gardella S, Carnero M, Lite JM, Casanova F, Martinez M, Fontanillas M, Feliu E, San Miguel JF, PETHEMA Group, Spanish Society of Hematology. Programa para el Estudio y Tratamiento de las Hemopatias Malignas (2001) Early and delayed consolidation chemotherapy significantly improves the outcome of children with intermediate-risk acute lymphoblastic leukemia. Final results of the prospective randomized PETHEMA ALL89 TRIAL. Haematologica 86: 586-595

Qiang Y-W, Endo Y, Rubin JS, Rudikoff S (2003) Wnt signaling in B-cell neoplasia. Oncogene 22: 1536-1545

Ribera JM, Ortega JJ, Oriol A, Fontanillas M, Hernandez-Rivas JM, Brunet S, Garcia-Conde J, Maldonado J, Zuazu J, Gardella S, Besalduch J, Leon P, Macia J, Domingo-Albos A, Feliu E, San Miguel JF (1998) Late intensification chemotherapy has not improved the results of intensive chemotherapy in adult acute lymphoblastic leukemia. Results of a prospective multicenter randomized trial (PETHEMA ALL-89). Haematologica 83: $222-230$

Ribera JM, Ortega JJ, Oriol A, Granada I, Hernandez-Rivas JM, Parody R, Bethencourt C, Rivas C, Bastida P, del Potro E, Gonzalez-Valentin ME, Moreno MJ, Besalduch J, Fernandez-Calvo J, Tormo M, Arias J, Molines A, Sanz MA, Maldonado J, Milla F, Feliu E, San Miguel JF, PETHEMA Group, Spanish Society of Hematology (2002) Prognostic value of karyotypic analysis in children and adults with high-risk acute lymphoblastic leukemia included in the PETHEMA ALL-93 trial. Haematologica 87: $154-166$

Roman-Gomez J, Castillejo JA, Jimenez A, Bornstein R, Gonzalez MG, del Carmen Rodriguez M, Barrios M, Maldonado J, Torres A (2001) Hypermethylation of the calcitonin gene in acute lymphoblastic 
leukaemia is associated with unfavourable clinical outcome. $\mathrm{Br} J$ Haematol 113: 329-338

Roman-Gomez J, Castillejo JA, Jimenez A, Gonzalez MG, Moreno F, Rodriguez Mdel C, Barrios M, Maldonado J, Torres A (2002) $5^{\prime}$ CpG island hypermethylation is associated with transcriptional silencing of the p21CIP1/WAF1/SDI1 gene and confers poor prognosis in acute lymphoblastic leukemia. Blood 99: 2291-2296

Roman-Gomez J, Jimenez A, Castillejo JA, Barrios M, Heiniger A, Torres A (2003) The role of DNA methylation in the pathogenesis and prognosis of acute lymphoblastic leukemia. Leuk Lymphoma 44: 1855-1864

Serrano M, Lin AW, McCurrach ME, Beach D, Lowe SE (1997) Oncogenic Ras provokes premature cell senescence associated with accumulation of p53 and p16. Cell 88: 593-602

Sheldahl LC, Park M, Malbon CC, Moon RT (1999) Protein kinase C is differentially stimulated by Wnt and Frizzled homologs in a G-proteindependent manner. Curr Biol 9: 695-698

Smith M, Arthur D, Camitta B, Carroll AJ, Crist W, Gaynon P, Gelber R, Heerema N, Korn EL, Link M, Murphy S, Pui CH, Pullen J, Reamon G,
Sallan SE, Sather H, Shuster J, Simon R, Trigg M, Tubergen D, Uckun F, Ungerleider $\mathrm{R}$ (1996) Uniform approach to risk classification and treatment assignment for children with acute lymphoblastic leukemia. J Clin Oncol 14: 18-24

Stein GH, Drullinger LF, Soulard A, Dulic V (1999) Differential roles for cyclin-dependent kinase inhibitors p16 and p21 in the mechanism of senescence and differentiation in human fibroblasts. Mol Cell Biol 19: 2109- 2117

Taipale J, Beachy PA (2001) The Hedgehog and Wnt signaling pathways in cancer. Nature 411: 349-354

Tsuji T, Miyazaki M, Sakaguchi M, Inoue Y, Namba M (2000) A REIC gene shows down-regulation in human immortalized cells and human tumor-derived cell lines. Biochem Biophys Res Commun 268: $20-24$

Tsuji T, Nozaki I, Miyazaki M, Sakaguchi M, Pu H, Hamazaki Y, Iijima O, Namba M (2001) Antiproliferative activity of REIC/Dkk-3 and its significant down-regulation in non-small-cell lung carcinomas. Biochem Biophys Res Commun 289: $257-263$ 